\title{
Synthesis, Characterization, and Biological Activity of 5-Phenyl-1,3,4-thiadiazole-2-amine Incorporated Azo Dye Derivatives
}

\author{
Chinnagiri T. Keerthi Kumar, ${ }^{1}$ Jathi Keshavayya, ${ }^{1}$ Tantry N. Rajesh, ${ }^{1}$ \\ Sanehalli K. Peethambar, ${ }^{2}$ and Angadi R. Shoukat Ali ${ }^{1}$ \\ ${ }^{1}$ Department of Studies and Research in Chemistry, School of Chemical Sciences, Kuvempu University, \\ Jnana Sahyadri, Shankaraghatta, Karnataka 577451, India \\ ${ }^{2}$ Department of Biochemistry, Kuvempu University, Jnana Sahyadri, Shankaraghatta, Karnataka 577451, India \\ Correspondence should be addressed to Jathi Keshavayya; jkeshavayya@gmail.com
}

Received 30 April 2013; Revised 25 June 2013; Accepted 27 June 2013

Academic Editor: Ashraf Aly Shehata

Copyright ( $) 2013$ Chinnagiri T. Keerthi Kumar et al. This is an open access article distributed under the Creative Commons Attribution License, which permits unrestricted use, distribution, and reproduction in any medium, provided the original work is properly cited.

\begin{abstract}
5-Phenyl-1,3,4-thiadiazole-2-amine has been synthesized by single step reaction. A series of heterocyclic azodyes were synthesized by diazotisation of 5-phenyl-1,3,4-thiadiazole-2-amine by nitrosyl sulphuric acid followed by coupling with different coupling compounds such as 8-hydroxyquinoline, 2,6-diaminopyridine, 2-naphthol, N,N-dimethyl aniline, resorcinol, and 4,6dihydroxypyrimidine. The dyes were characterized by UV-Vis, IR, ${ }^{1} \mathrm{H}-\mathrm{NMR},{ }^{13} \mathrm{C} \mathrm{NMR}$, and elemental analysis. The synthesized compounds were also screened for biological activity.
\end{abstract}

\section{Introduction}

Azo dyes are the most widely used class of colouring materials because of their massive applications in various fields of science and technology [1-3]. The azo dyes are synthesized by diazotization of aromatic amines and coupling reagent, which include one or more azo groups $(-\mathrm{N}=\mathrm{N}-)$ attached to one or more aromatic moieties (Karci et al. [4]). These dyes play a major role in textile, printing, leather, papermaking, drug (Torres et al. [5]) and food industries (Yousefi et al. [6]). Heterocyclic azo dyes have wide applications as high leveldying agents in the dyestuff industries (Hallas and Choi [7]). It has been known that the activity of azo linkage increases with the incorporation of suitable heterocyclic moiety. The increasing usage of these dyes in electronic industry, such as colorimetric sensors, nonlinear optical (NLO) devices and liquid crystalline displays (LCDs) used as potential sensitizers for photodynamic therapy (PDT) has attracted much attention (Demirbas et al. [8]). Nowadays, much attention has been focused on 1,3,4-thiadiazole derivatives as a very important class of nitrogen-containing aromatic heterocyclic compounds due to their diverse biological activities such as antitumor [9, 10], antibacterial [11, 12], anti-inflammatory, antimycotic (Fernandez et al. [13]), and powerful antifungal agents (Waring and Hallas [14]). In contrast, 1,3,4-thiadiazole derivatives exhibits a broad spectrum of biocidal activities possibly due to the presence of toxophoric-N-C-S moiety (Mavrova et al. [15]).

With these objects in view and also work carried out in our lab on this class of azo dyes [16, 17], we now focus on synthesis and screening for antimicrobial and antioxidant activities of 5-phenyl-1,3,4-thiadiazole-2-amine containing azo group in their structure. 5-phenyl-1,3,4thiadiazole-2-amine was synthesized by single step reaction and it was transformed to its corresponding diazonium salt by diazotization reaction and was further coupled with various coupling agents (8-hydroxy quinoline, 2,6diaminopyridine N,N-dimethyl aniline, 2-naphthol, resorcinol, and 4,6-dihydroxypyrimidine) under suitable experimental reaction. 
<smiles>[R]N=Nc1nnc(-c2ccccc2)s1</smiles><smiles></smiles><smiles></smiles>

SCHEMe 1

\section{Materials and Measurements}

All the starting materials were obtained from Merck and were used without further purification. Melting points were measured using standard melting point apparatus from Sunder Industrial Products (India) and were uncorrected. The UV-Visible absorption spectra were recorded in DMSO with a SHIMADZU UV-1800 spectrometer at concentration range of $10^{-4} \mathrm{M}$. IR spectra were recorded in the region of $4000 \mathrm{~cm}^{-1}$ to $400 \mathrm{~cm}^{-1}$ on an FT-IR-Alpha Bruker IR spectrometer in $\mathrm{KBr}$ pellets. The ${ }^{1} \mathrm{H}$-and ${ }^{13} \mathrm{C}$-NMR spectra were recorded in DMSO-d6 at $500 \mathrm{MHz}$ using AV500High Resolution Multinuclear FT-NMR Spectrometer with tetramethylsilane as internal standard.

\section{Experimental}

3.1. Synthesis of 5-Phenyl-1,3,4-thiadiazol-2-amine (1). Benzoic acid $(0.1 \mathrm{~mol})$ and thiosemicarbazide $(0.1 \mathrm{~mol})$ in phosphorous oxychloride $(30 \mathrm{~mL})$ were refluxed gently for $30 \mathrm{~min}$ and cooled followed by careful addition of water $(90 \mathrm{~mL})$. The separated solid was filtered and suspended in water and basified with aqueous potassium hydroxide followed by filtration, drying, and crystallization from mixture of DMF and ethanol $(9: 1)$ to obtain colourless solid with $65 \%$ yield. IR $\left[(\mathrm{KBr}) v_{\max } / \mathrm{cm}^{-1}\right]: 3087$ (aromatic C-H), $1613(\mathrm{C}=\mathrm{N}), \mathrm{cm}^{-1}$; ${ }^{1} \mathrm{H}-\mathrm{NMR}$ (DMSO-d6): 7.2-7.5 (m, 5H), 5.1 (s, 2H); ${ }^{13} \mathrm{C}-\mathrm{NMR}$ (DMSO-d6, ppm): $153.9(\mathrm{C}-\mathrm{O}), 130.4(\mathrm{C}-\mathrm{N}), 174.6(\mathrm{C}=\mathrm{N})$, $150.8(\mathrm{C}-\mathrm{N})$. LC-MS $(\mathrm{m} / z) 177.2$; anal. calcd. for $\mathrm{C}_{8} \mathrm{H}_{7} \mathrm{~N}_{3} \mathrm{~S}$ : C,54.22; H,3.98; N,23.71; found: C,54.19; H,3.95; N,22.69.
3.2. General Procedure for Preparation of Dye 3(a-f). 5Phenyl-1,3,4-thiadiazole-2-amine $\left(2.0 \times 10^{-3} \mathrm{~mol}\right)$ was dissolved in hot glacial acetic acid/propionic acid mixture $(2: 1$, $6.0 \mathrm{~mL}$ ) and was rapidly cooled in an ice/salt bath to $-5^{\circ} \mathrm{C}$. The liquor was then added in portions during $30 \mathrm{~min}$ to a cold solution of nitrosyl sulphuric acid (prepared from sodium nitrite $(0.15 \mathrm{~g})$ and concentrated sulphuric acid $(3 \mathrm{~mL})$ at $50^{\circ} \mathrm{C}$ ). The mixture was stirred for an additional $2 \mathrm{hrs}$ at $0^{\circ} \mathrm{C}$. Excess nitrous acid was destroyed by addition of urea. The resulting diazonium salt was cooled in salt/ice mixture. After diazotization was complete, the diazo liquor was slowly added to vigorously stirred solution of coupling component $\left(2.0 \times 10^{-3} \mathrm{~mol}\right)$ in potassium hydroxide $\left(2.0 \times 10^{-3} \mathrm{~mol}\right)$ and water $(2 \mathrm{~mL})$. The solution was stirred at $0-5^{\circ} \mathrm{C}$ for $2 \mathrm{~h}$. After $2 \mathrm{~h}$, the $\mathrm{pH}$ of the reaction mixture was maintained at $4-6$ by the simultaneous addition of saturated sodium carbonate solution. The mixture was stirred for one day at room temperature. After one day, the resulting solid was filtered, washed with cold water, and dried.

The general scheme for the syntheses is given in Scheme 1 .

3.3. Preparation of 5-[(5-Phenyl-1,3,4-thiadiazol-2-yl)diazenyl]quinolin-8-ol: [3a]. The dye was obtained from 5-phenyl1,3,4-thiadiazol-2-amine and 8-hydroxy quinoline as brown crystals (yield: $46 \%$, m.p: 218$)$. IR [(KBr) $\left.v_{\max } / \mathrm{cm}^{-1}\right]: 3553-$ 3312 (broad -OH group), 3063 (aromatic C-H), $1573(\mathrm{C}=\mathrm{N})$, $1530(\mathrm{~N}=\mathrm{N}) \mathrm{cm}^{-1} ;{ }^{1} \mathrm{H}-\mathrm{NMR}$ (DMSO-d6): $8.9(\mathrm{~d}, 1 \mathrm{H})$, $8.6(\mathrm{~d}, 1 \mathrm{H}), 7.9(\mathrm{t}, 2 \mathrm{H}), 6.80(\mathrm{~d}, 1 \mathrm{H}), 7.2-7.5(\mathrm{~m}, 5 \mathrm{H})$, 
5.1 (s, 1H); ${ }^{13} \mathrm{C}-\mathrm{NMR}$ (DMSO-d6, ppm): 153.9 (C-O), 130.4 $(\mathrm{C}-\mathrm{N}), 174.6(\mathrm{C}=\mathrm{N}), 150.8(\mathrm{C}-\mathrm{N}$, quinoline); anal. calcd. for $\mathrm{C}_{17} \mathrm{H}_{11} \mathrm{~N}_{5}$ OS: C,61.25; H,3.33; N,21.01; found: C,61.22; H,3.31; $\mathrm{N}, 20.99$.

3.4. Preparation of 3-[(5-Phenyl-1,3,4-thiadiazol-2-yl)diazenyl]pyridine-2,6-diamine: [3b]. This dye was prepared from 5phenyl-1,3,4-thiadiazol-2-amine and 2,6-diamino pyridine as wine red crystals (yield: 57\%, m.p: 178). IR [(KBr) $\left.v_{\max } / \mathrm{cm}^{-1}\right]$ : absorptions bands at $3335 \mathrm{~cm}^{-1}, 3063$ (aromatic C-H), 1580 $(\mathrm{C}=\mathrm{N}), 1631 \mathrm{~cm}^{-1}(\mathrm{~N}-\mathrm{H}$ aromatic $), 1490 \mathrm{~cm}^{-1}(\mathrm{~N}=\mathrm{N}) .{ }^{1} \mathrm{H}-$ NMR (DMSO-d6): 7.22-7.48 (m, 5H), 7.7 (d, 1H), 6.2 (d, 1H) $4.2(\mathrm{~s}, 4 \mathrm{H}),{ }^{13} \mathrm{C}-\mathrm{NMR}$ (DMSO-d6, ppm): $158.6(\mathrm{C}=\mathrm{N}$, pyridine), $156.9(\mathrm{C}-\mathrm{N}), 175.5(\mathrm{C}=\mathrm{N}$, thiadiazole $)$; anal. calcd. for $\mathrm{C}_{13} \mathrm{H}_{11} \mathrm{~N}_{7} \mathrm{~S}$ : C,52.51; H,3.73; N,32.97; found: C,52.49; $\mathrm{H}, 3.70 ; \mathrm{N}, 32.94$.

3.5. Preparation of N,N-dimethyl-4-[(5-phenyl-1,3,4-thiadiazol-2-yl)diazenyl]aniline: [3c]. This dye was synthesized from 5-phenyl-1,3,4-thiadiazol-2-amine and N,N-dimethyl aniline as dark red crystals (yield: 71\%, m.p: 191). IR [(KBr) $v_{\max } / \mathrm{cm}^{-1}$ ]: 3056 (aromatic C-H), 2940 (aliphatic C-H), $1562(\mathrm{C}=\mathrm{N}) \mathrm{cm}^{-1} ; 1496(\mathrm{~N}=\mathrm{N}) \mathrm{cm}^{-1} ;{ }^{1} \mathrm{H}-\mathrm{NMR}$ (DMSOd6): $2.85(\mathrm{~d}, 6 \mathrm{H}), 7.2(\mathrm{~d}, 2 \mathrm{H}), 6.8(\mathrm{~d}, 2 \mathrm{H}) 7.25-7.6(\mathrm{~m}, 5 \mathrm{H})$, ${ }^{13}$ C-NMR (DMSO-d6, ppm): $40.9\left(\mathrm{CH}_{3}\right), 150.2(\mathrm{C}-\mathrm{N}), 175.9$ (C=N, Thiadiazole), 150.1 (C-N, aniline), 119.1 (C-N, Azo); anal. calcd. for $\mathrm{C}_{16} \mathrm{H}_{15} \mathrm{~N}_{5} \mathrm{~S}$ : C,62.11; H,4.89; N,22.64; found: C,62.09; H,4.87; N,22.61.

3.6. Preparation of 1-[(5-Phenyl-1,3,4-thiadiazol-2-yl)diazenyl]naphthalen-2-ol: [3d]. This dye was obtained from 5phenyl-1,3,4-thiadiazol-2-amine and 2-naphthol as brick red crystals (yield: $66 \%$, m.p: 182). IR [(KBr) $\left.v_{\max } / \mathrm{cm}^{-1}\right]$ : 34393397 (broad -OH group), 3031 (aromatic C-H), $1550(\mathrm{C}=\mathrm{N})$ $\mathrm{cm}^{-1}, 1475(\mathrm{~N}=\mathrm{N}) \mathrm{cm}^{-1} ;{ }^{1} \mathrm{H}-\mathrm{NMR}$ (DMSO-d6): 7.1 (d, 1H), 7.5-7.6 (d, 3H), 7.2-7.4 (m, 7H) 14.1 (s, 1H); ${ }^{13} \mathrm{C}-\mathrm{NMR}$ (DMSOd6,ppm): $162.9(\mathrm{C}-\mathrm{O}), 123.2(\mathrm{C}-\mathrm{N}), 175.8(\mathrm{C}=\mathrm{N})$; anal. calcd. for $\mathrm{C}_{18} \mathrm{H}_{12} \mathrm{~N}_{4}$ OS: C,65.04; $\mathrm{H}, 3.64 ; \mathrm{N}, 16.86$; found: C,65.01; $\mathrm{H}, 3.61 ; \mathrm{N}, 16.82$.

3.7. Preparation of 4-[(5-Phenyl-1,3,4-thiadiazol-2-yl)diazenyl]benzene-1,3-diol: [3e]. This dye was prepared from 5phenyl-1,3,4-thiadiazol-2-amine and resorcinol as red crystals (yield: 61\%, m.p: 182). IR [(KBr) $\left.v_{\max } / \mathrm{cm}^{-1}\right]$ : 3421-3385 (broad O-H group), 3031 (aromatic C-H), $1557(\mathrm{C}=\mathrm{N}) \mathrm{cm}^{-1}$; $1510(\mathrm{~N}=\mathrm{N}) \mathrm{cm}^{-1} ;{ }^{1} \mathrm{H}-\mathrm{NMR}$ (DMSO-d6): 7.1-7.5 (m, 5H), 5.2 $(\mathrm{s}, 2 \mathrm{H}), 6.2(\mathrm{~d}, 1 \mathrm{H}) 6.4(\mathrm{~s}, 1 \mathrm{H}), 6.9(\mathrm{~s}, 1 \mathrm{H}) ;{ }^{13} \mathrm{C}-\mathrm{NMR}$ (DMSOd6, ppm): 162.9 (C-O), $123.2(\mathrm{C}-\mathrm{N}), 175.8(\mathrm{C}=\mathrm{N})$; anal. calcd. for $\mathrm{C}_{14} \mathrm{H}_{10} \mathrm{~N}_{4} \mathrm{O}_{2} \mathrm{~S}$ : C,56.37; H,3.38; N,18.78; found: C,56.33; $\mathrm{H}, 3.34$; N,18.82.

3.8. Preparation of 5-[(5-Phenyl-1,3,4-thiadiazol-2-yl)diazenyl]pyrimidine-4,6-diol: [3f]. This dye was synthesised from 5-phenyl-1,3,4-thiadiazol-2-amine and 4,6-dihydroxy pyrimidine as orange crystals (yield: 61\%, m.p: 182). IR [(KBr) $v_{\max } / \mathrm{cm}^{-1}$ ]: 3438-3391 (broad $\mathrm{O}-\mathrm{H}$ group), 3031 (aromatic $\mathrm{C}-\mathrm{H}), 1564(\mathrm{C}=\mathrm{N}) \mathrm{cm}^{-1} ; 1527(\mathrm{~N}=\mathrm{N}) \mathrm{cm}^{-1} ;{ }^{1} \mathrm{H}-\mathrm{NMR}$
(DMSO-d6): 5.1 (d, 2H), 7.2-7.5 (d, 5H), $7.6(\mathrm{~d}, 1 \mathrm{H}),{ }^{13} \mathrm{C}-\mathrm{NMR}$ (DMSO-d6, ppm): $162.9(\mathrm{C}-\mathrm{O}), 123.2(\mathrm{C}-\mathrm{N}), 175.8(\mathrm{C}=\mathrm{N})$; anal. calcd. for $\mathrm{C}_{12} \mathrm{H}_{8} \mathrm{~N}_{6} \mathrm{O}_{2} \mathrm{~S}$ : C,48.00; $\mathrm{H}, 2.69 ; \mathrm{N}, 27.99$; found: C,47.97; H,2.67; N,27.96.

\section{Biological Activity}

4.1. Bacterial and Fungal Strains. The following bacteria and fungi were used for the experiment. Bacteria: Staphylococcus aureus ATCC 25923, Escherichia coli ATCC 25922, and Pseudomonas aeruginosa ATCC 27853. All bacterial strains were maintained on nutrient agar medium at $37^{\circ} \mathrm{C}$. Fungi: Aspergillus flavus, Chrysosporium keratinophilum, and Candida albicans MTCC 227 are used in this study. These cultures are obtained from the Department of Microbiology, Kuvempu University. All fungi strains were maintained on potato dextrose agar (PDA) at $25^{\circ} \mathrm{C}$.

4.2. Antibacterial and Antifungal Activities. The antimicrobial activity of newly synthesized compounds was evaluated using agar disc diffusion assay $[18,19]$. Briefly, a 24-hour old culture of bacteria and 48-hour old culture of fungi were mixed with sterile physiological saline $(0.9 \%)$ and the turbidity was adjusted to the standard inoculum of MacFarland scale $0.5\left(10^{6}\right.$ colony forming units (CFU) per $\mathrm{mL}$ ). Petri plates containing $20 \mathrm{~mL}$ of Mueller Hinton agar and Sabouraud-dextrose agar were used for antibacterial and antifungal activities. The inoculums were spread on the surface of the solidified media and Whatman No. 1 filter paper discs ( $5 \mathrm{~mm}$ in diameter) impregnated with the test compound ( $20 \mu \mathrm{L} / \mathrm{disc})$ were placed on the solidified media. Streptomycin ( $5 \mathrm{mg} / \mathrm{disc})$ and fluconazole $(5 \mathrm{mg} / \mathrm{disc})$ were used as positive controls for bacteria and fungi, respectively, along with DMSO disc as negative control. Zone of inhibition was recorded in millimeters after incubating bacterial strains at $37^{\circ} \mathrm{C}(24 \mathrm{hr})$ and fungal strains at $25^{\circ} \mathrm{C}(72 \mathrm{hr})$. Tests were performed in triplicate and the values were expressed as mean \pm SD $[18,20,21]$.

4.3. Minimal Inhibitory Concentrations (MIC). The in vitro determination of the minimum inhibitory concentration (MIC) against selected bacterial strains was carried out using serial dilution method (Table 4). The agar dilution susceptibility test was performed based on the reported method by Shridhar [22] to determine the MIC of the synthesized compounds. The test compounds $\mathbf{3}(\mathbf{a}-\mathbf{f})$ dissolved in sterilized $5 \%$ DMSO (400 mg/mL concentration) were taken as standard stock. A series of twofold dilutions of each compound in the final concentrations of 400, 300, $200,100,50,25,13$, and $7 \mathrm{mg} / \mathrm{mL}$ were prepared in nutrient agar for bacteria. After solidification, the plates were spotted with $100 \mu \mathrm{L}$ of overnight grown bacterial cultures approximately containing $1 \times 10^{4} \mathrm{CFU} / \mathrm{mL}$. The test was carried out in triplicate. The plates of bacterial culture were incubated at $37^{\circ} \mathrm{C}$ for $18-24 \mathrm{~h}$. After incubation, the MIC was determined. 
TABLE 1: Yield, melting point, $\lambda_{\max }$, molar absorptivity $(\varepsilon)$, molecular formula, and solubility data of dye $\mathbf{3}(\mathbf{a}-\mathbf{f})$.

\begin{tabular}{lccccccc}
\hline Dye & Yield $(\%)$ & MP $\left({ }^{\circ} \mathrm{C}\right)$ & $\lambda_{\text {max }}$ in $\mathrm{nm}$ & $\log \varepsilon$ & Molecular formula & Mol. wt. & Solubility \\
\hline 3a & $46 \%$ & $216-218$ & 490 & 4.2 & $\mathrm{C}_{17} \mathrm{H}_{11} \mathrm{~N}_{5} \mathrm{OS}$ & 333.36 & Acetone/Ethanol/DMF/DMSO \\
3b & $57 \%$ & $169-171$ & 488 & 4.51 & $\mathrm{C}_{13} \mathrm{H}_{11} \mathrm{~N}_{7} \mathrm{~S}$ & 297.33 & Acetone/Ethanol/DMF/DMSO \\
3c & $71 \%$ & $189-191$ & 512 & 4.02 & $\mathrm{C}_{16} \mathrm{H}_{15} \mathrm{~N}_{5} \mathrm{~S}$ & 309.38 & Acetone/Ethanol/DMF/DMSO \\
3d & $66 \%$ & $179-182$ & 525 & 4.58 & $\mathrm{C}_{18} \mathrm{H}_{12} \mathrm{~N}_{4} \mathrm{OS}$ & 332.37 & Acetone/Ethanol/DMF/DMSO \\
3e & $61 \%$ & $192-194$ & 509 & 4.17 & $\mathrm{C}_{14} \mathrm{H}_{10} \mathrm{~N}_{4} \mathrm{O}_{2} \mathrm{~S}$ & 298.31 & Acetone/Ethanol/DMF/DMSO \\
3f & $54 \%$ & $202-204$ & 498 & 4.3 & $\mathrm{C}_{12} \mathrm{H}_{8} \mathrm{~N}_{6} \mathrm{O}_{2} \mathrm{~S}$ & 300.29 & Acetone/DMSO Ethanol/DMF \\
\hline
\end{tabular}

\subsection{Antioxidant Activity}

4.4.1. DPPH Activity. The antioxidant capacity of newly synthesised compounds was determined by the reported method of Blois [23] with suitable modifications. The reaction mixture contained $3 \mathrm{~mL}$ of $0.1 \mathrm{mM}$ DPPH in $95 \%$ methanol and $100 \mu \mathrm{L}$ of solution of different organic compounds from the stock solution $(1 \mathrm{mg} / \mathrm{mL})$, and final volume was made up to $4 \mathrm{~mL}$ with $95 \%$ ethanol. The mixture was kept at room temperature for $20 \mathrm{~min}$ in the dark, and then the absorbance was recorded at $517 \mathrm{~nm}$. The $95 \%$ methanol was used as a control. The scavenging activity of DPPH radicals (\%) was calculated by the following equation:

$\%$ of inhibition

$$
=\frac{(\text { abs. of the control }- \text { abs. of the test sample })}{\text { abs. of the control }} \times 100 \text {. }
$$

4.4.2. Metal Chelating Activity. The metal chelating properties of newly synthesised compounds were determind using reported the procedure by Dinis [24]. Briefly, $100 \mu \mathrm{L}$ of newly synthesised compounds in methanol was added to a solution of $2 \mathrm{mM} \mathrm{FeCl}_{2}(0.05 \mathrm{~mL})$. The reaction was initiated by adding $5 \mathrm{mM}$ ferrozine $(0.2 \mathrm{~mL})$ and the mixture was shaken vigorously and kept at room temperature for $10 \mathrm{~min}$. After the mixture had reached equilibrium, the absorbance of the solution was then measured spectrophotometrically at $562 \mathrm{~nm}$. All the tests and analyses were run in triplicate. The percentage of inhibition of ferrozine- $\mathrm{Fe}^{2+}$ complex formation is given by the following equation:

$$
\text { inhibition }(\%)=\left[\frac{\left(A_{\text {cont }}-A_{\text {test }}\right)}{A_{\text {cont }}}\right] \times 100 \text {, }
$$

where $A_{\text {cont }}$ is the absorbance of the control and $A_{\text {test }}$ is the absorbance of the test sample/standard.

\section{Result and Discussion}

5.1. Synthesis and Characterization. As shown in Scheme 1, the hetarylazo dyes $\mathbf{3}(\mathbf{a}-\mathbf{f})$ were prepared through the diazotization of 5-phenyl-1,3,4-thiadiazol-2-amine and coupled with different coupling components such as 8-hydroxyquinoline, 2,6-diamino pyridine, N,N dimethyl aniline, 2-naphthol, resorcinol, and 4,6-dihydroxypyrimidine. The synthesized dyes were characterized by FT-IR, UV-Vis, ${ }^{1} \mathrm{H}-\mathrm{NMR},{ }^{13} \mathrm{C}$ NMR, and elemental analysis.

The infrared spectra of all the dyes (in $\mathrm{KBr}$ ) were recorded in the region of $4000 \mathrm{~cm}^{-1}$ to $400 \mathrm{~cm}^{-1}$. For the dyes 3a, 3d, $\mathbf{3 e}$ and $\mathbf{3 f}$ a broad band has appeared at the region 3500-3200 which confirms the presence of hydroxyl group $(-\mathrm{OH})$. These dyes $3(\mathbf{a}-\mathbf{f})$ are showed $1517-1535 \mathrm{~cm}^{-1}$ for $(\mathrm{N}=\mathrm{N})$ azo group. The $v_{\max }$ values at $3085-3005 \mathrm{~cm}^{-1}$ (aromatic $\mathrm{C}-\mathrm{H}$ ) and at $2986-2851 \mathrm{~cm}^{-1}$ (aliphatic C-H) were also observed.

The ${ }^{1} \mathrm{H}-\mathrm{NMR}$ spectra were recorded in DMSO-d6 in dye $3 \mathrm{c}$ singlet at $2.85 \mathrm{ppm}$ for $-\left(\mathrm{CH}_{3}\right)_{2}$ group of N,N-dimethyl aniline, a multiplet from 7.20 to $7.50 \mathrm{ppm}$ for aromatic protons $(\mathrm{Ar}-\mathrm{H})$. In dyes $\mathbf{3}(\mathbf{a}-\mathbf{f})$, the signals within the range of $7.25-$ $7.6 \mathrm{ppm}$ are attributable to aromatic protons on the 5-phenyl 1,3,4-thiadiazole. The signal of the four protons on the two amino groups of dye (3b) was not clearly observed in ${ }^{1} \mathrm{H}$ NMR spectrum of dye ( $3 \mathbf{b})$ because they were acidic hydrogen atoms, which could exchange with deuterium atoms of solvent (Pavia et al. [25]).

These dyes were in good yield and these are soluble in acetone, DMF, and DMSO. Absorption spectra of the azo dyes $\mathbf{3}(\mathbf{a}-\mathbf{f})$ were recorded in DMSO at a concentration of $10^{-4} \mathrm{~mol} \mathrm{~L}^{-1}$. Due to $\pi-\pi^{*}$ electronic transition in azo group, the absorption maxima of the dyes $\mathbf{3}(\mathbf{a}-\mathbf{f})$ lie in the range of 485 to 528 with the marginal variation. The results are summarized in Table 1 and Figure 1.

5.1.1. Antimicrobial Effect. The capacity of antimicrobial activity of the six newly synthesized compounds against six ( 3 bacteria and 3 fungi) human pathogenic microorganisms were assessed both qualitatively and quantitatively by the presence or the absence of inhibition zone and MIC values with standard drugs (streptomycin and fluconazole). The results of antibacterial activities of the extracts are shown in Table 2. The result shows that the synthetized compounds showed lower antimicrobial activities than thoes of standard. The compounds $\mathbf{3 a}(50,25,50$ of MIC), 3b (100, 50, 50 of MIC), and $3 f$ (100, 100, 100 of MIC) show good and comparable activity than that of standard. According to Scorzoni [26], the compounds show an MIC less than $75 \mu \mathrm{g} / \mathrm{mL}$ considered to have strong antimicrobial activity, from 75 to $150 \mu \mathrm{g} / \mathrm{mL}$ the activity is considered as moderate, from 150 to $250 \mu \mathrm{g} / \mathrm{mL}$ the antimicrobial activity was weak, and over $250 \mu \mathrm{g} / \mathrm{mL}$ the compounds were considered as inactive. Therefore, in the present work all synthesized compounds possessed strong, moderate, and weak activities against all 
TABLE 2: In vitro antibacterial activities of the compounds $\mathbf{3}(\mathbf{a}-\mathbf{f})$.

\begin{tabular}{|c|c|c|c|c|c|c|c|}
\hline \multirow{3}{*}{ Sl. no. } & \multirow[b]{3}{*}{ Conc. in $\mathrm{mg} / \mathrm{mL}$} & \multirow{2}{*}{\multicolumn{2}{|c|}{ Escherichia coli }} & \multirow{2}{*}{\multicolumn{3}{|c|}{$\begin{array}{l}\text { Staphylococcus aureus } \\
\text { Diameter of zone of inhibition (mm) }\end{array}$}} & Pseudomonas aeruginosa \\
\hline & & & & & & & \\
\hline & & 1 & 0.5 & 1 & 0.5 & 1 & 0.5 \\
\hline 1 & Control & \multicolumn{2}{|c|}{00} & \multicolumn{2}{|c|}{00} & \multicolumn{2}{|c|}{00} \\
\hline 2 & Standard streptomycin & $16 \pm 0.2$ & $10 \pm 0.3$ & $15 \pm 0.4$ & $10 \pm 0.5$ & $16 \pm 0.3$ & $13 \pm 0.6$ \\
\hline 3 & $3 \mathbf{a}$ & $13 \pm 0.5$ & $10 \pm 0.7$ & $14 \pm 0.6$ & $12 \pm 0.3$ & $10 \pm 0.5$ & $08 \pm 0.5$ \\
\hline 4 & $3 b$ & $12 \pm 0.4$ & $09 \pm 0.6$ & $12 \pm 0.4$ & $10 \pm 0.5$ & $13 \pm 0.3$ & $11 \pm 0.2$ \\
\hline 5 & $3 c$ & $04 \pm 0.2$ & $01 \pm 0.2$ & $02 \pm 0.5$ & 00 & $03 \pm 0.3$ & $01 \pm 0.1$ \\
\hline 6 & $3 d$ & $08 \pm 0.4$ & $06 \pm 0.5$ & $09 \pm 0.6$ & $07 \pm 0.3$ & $08 \pm 0.2$ & $05 \pm 0.7$ \\
\hline 7 & $3 e$ & $06 \pm 0.6$ & $04 \pm 0.2$ & $08 \pm 0.7$ & $05 \pm 0.3$ & $07 \pm 0.2$ & $05 \pm 0.5$ \\
\hline 8 & $3 f$ & $10 \pm 0.6$ & $07 \pm 0.2$ & $11 \pm 0.8$ & $08 \pm 0.2$ & $10 \pm 0.1$ & $07 \pm 0.3$ \\
\hline
\end{tabular}

test bacteria. Although a comparable antibacterial activity was exhibited by few compounds, these compounds failed to show a good response to antifungal activity, and the compound $3 \mathrm{c}$ does not show any antimicrobial property.

5.1.2. Antioxidant Activity. The DPPH radical scavenging activity is a widely used method to evaluate the antioxidant capacity of newly synthetized compounds due to its short time reaction compared to other methods. The ability to donate hydrogen or electron to the DPPH radicals is thought to be the reason for the antioxidant property of organic compounds (Baumann et al. [27]). The DPPH radicals easily expcept the electron or hydrogen atom from the organic molecules to form stable diamagnetic molecules Soares et al. [28]. The DPPH lose its colour and the absorbance of the $\mathrm{DPPH}$ also decreases which is read at $517 \mathrm{~nm}$. Scavenging effects of newly synthesised compounds $\mathbf{3 a}, \mathbf{3 b}$ and $\mathbf{3 f}$ show good and comparable value to standard (Figure 2) on the other hand, remaining compounds are showing moderate scavenging activity when compared to standard BHT. However, the scavenging effects of BHT are higher than of all newly synthesized compounds.

5.1.3. Metal Chelating Activity. The ferrozine can bind to $\mathrm{Fe}^{2+}$ ions quantitatively to form stable complexes. In the presence of chelating agents like organic compounds and plant extracts, the complex formation is disrupted which results in the destabilization of complex and results in decreases in the red colour of complex. Measurement of the decrease in the colour allows us to estimate the chelating property of the organic compounds or coexisting chelator (Yamaguchi [29]). In the present work the organic compounds and standard destabilize the complex of ferrous and ferrozine, suggesting that they have a chelating capacity. The metal like iron can stimulate the lipid peroxidation by the Fenton reaction and it also stimulates the peroxidation by decomposing lipid hydroperoxides into peroxyl and alkoxyl free radicals that can themselves abstract hydrogen and perpetuate the chain reaction of lipid peroxidation (Halliwell [30]). The compounds $\mathbf{3} \mathbf{a}, \mathbf{3} \mathbf{b}$ and $\mathbf{3} \mathbf{f}$ shows good activity than the other compounds indicates the capacity of these compounds to

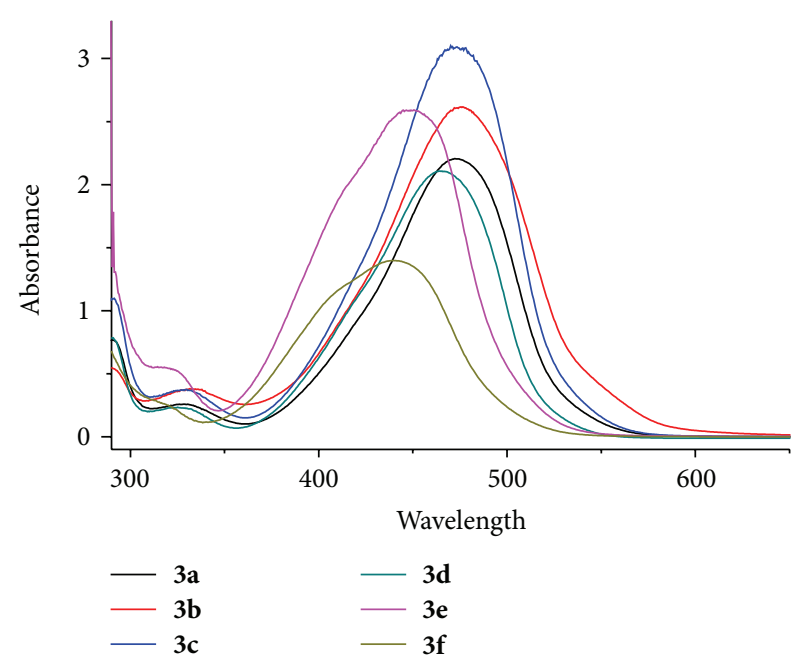

Figure 1: Absorption spectra of dyes 3(a-f) in DMSO.

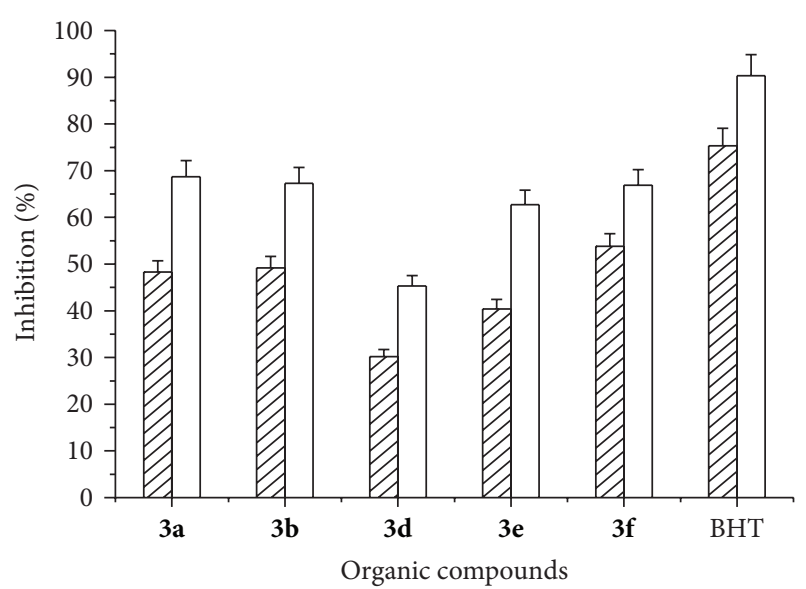

FIGURE 2: DPPH radical scavenging activity.

destabilize the complex between the ferrozine and $\mathrm{Fe}^{2+}$ ions. But the remaining compounds fail to chelate the metal ions as compared to standard. 
TABLE 3: In vitro antifungal activities of the compounds 3(a-f).

\begin{tabular}{|c|c|c|c|c|c|c|c|}
\hline \multirow[t]{2}{*}{ Sl. no. } & \multirow[b]{2}{*}{ Conc. in $\mathrm{mg} / \mathrm{mL}$} & \multicolumn{2}{|c|}{ Aspergillus flavus } & \multicolumn{2}{|c|}{$\begin{array}{c}\text { Chrysosporium keratinophilum } \\
\text { Diameter of zone of inhibition ( } \mathrm{mm})\end{array}$} & \multicolumn{2}{|c|}{ Candida albicans } \\
\hline & & 1 & 0.5 & 1 & 0.5 & 1 & 0.5 \\
\hline 1 & Control & \multicolumn{2}{|c|}{00} & \multicolumn{2}{|c|}{00} & \multicolumn{2}{|c|}{00} \\
\hline 2 & Standard flucanazole & $18 \pm 0.5$ & $15 \pm 0.3$ & $16 \pm 0.7$ & $14 \pm 0.2$ & $23 \pm 0.8$ & $20 \pm 0.3$ \\
\hline 3 & $3 a$ & $09 \pm 0.5$ & $06 \pm 0.3$ & $10 \pm 0.7$ & $08 \pm 0.8$ & $11 \pm 0.5$ & $07 \pm 0.2$ \\
\hline 4 & $3 b$ & $05 \pm 0.6$ & $03 \pm 0.3$ & $04 \pm 0.6$ & $01 \pm 0.4$ & $04 \pm 0.2$ & $01 \pm 0.1$ \\
\hline 5 & $3 c$ & $04 \pm 0.3$ & $02 \pm 0.2$ & $05 \pm 0.3$ & $03 \pm 0.6$ & $03 \pm 0.3$ & $02 \pm 0.1$ \\
\hline 6 & $3 d$ & $08 \pm 0.4$ & $06 \pm 0.5$ & $09 \pm 0.6$ & $07 \pm 0.3$ & $08 \pm 0.2$ & $05 \pm 0.7$ \\
\hline 7 & $3 e$ & $06 \pm 0.6$ & $04 \pm 0.2$ & $08 \pm 0.7$ & $05 \pm 0.3$ & $07 \pm 0.4$ & $05 \pm 0.3$ \\
\hline 8 & $3 f$ & $13 \pm 0.5$ & $10 \pm 0.5$ & $14 \pm 0.3$ & $11 \pm 0.1$ & $15 \pm 0.7$ & $13 \pm 0.5$ \\
\hline
\end{tabular}

TABLE 4: Minimum inhibitory concentration compounds 3(a-f).

\begin{tabular}{lcccc}
\hline \multirow{2}{*}{ Sl. no. Compounds } & \multicolumn{3}{c}{ Concentration in $\mu \mathrm{g} / \mathrm{mL}$} \\
& $\begin{array}{c}\text { Escherichia } \\
\text { coli }\end{array}$ & $\begin{array}{c}\text { Staphylococcus } \\
\text { aureus }\end{array}$ & $\begin{array}{c}\text { Pseudomonas } \\
\text { aeruginosa }\end{array}$ \\
\hline 1 & 3a & 50 & 25 & 50 \\
2 & 3b & 100 & 50 & 50 \\
3 & 3c & 400 & - & 400 \\
4 & 3d & 200 & 200 & 200 \\
5 & 3e & 400 & 200 & 200 \\
6 & 3f & 100 & 100 & 100 \\
\hline
\end{tabular}

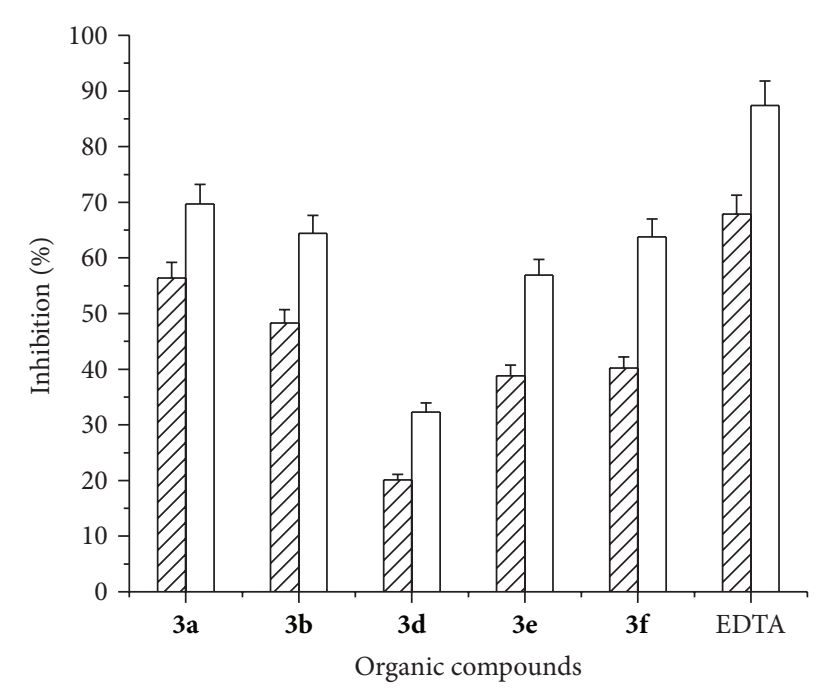

FIgURE 3: Metal chelating activity.

5.1.4. Biological Activity. See Tables 2 and 3.

5.1.5. Antioxidant Activity. See Figures 2 and 3.

\section{Conclusions}

In this work, 6 new heterocyclic azo dyes were synthesized by a classical method of diazotizing coupling. This investigation proposes a convenient, economical, cheaper, and useful method for the synthesis of 5-phenyl-1,3,4-thiadiazole-azo dyes, coupled with quinoline, which are biologically active molecules possessing antimicrobial and in vitro antioxidant properties. These new classes of heterocycles exhibit significant antimicrobial and antioxidant activities. 1,3,4-Thiadiazol azo dye coupled with 8-hydroxy quinoline showed higher active antioxidant capacity than 1,3,4-thiadiazol azo dye coupled with naphthol. The preliminary antimicrobial activity studies revealed that the azo dye having 1,3,4-thiadiazole moiety exhibited a potential antimicrobial activity. Hence, it can be concluded that this new class of compounds certainly holds a greater promise in discovering a potent antimicrobial and antioxidant agent.

\section{References}

[1] M. Dakiky and I. Nemcova, "Aggregation of $o, o^{\prime}$-dihydroxy azo dyes III. Effect of cationic, anionic and non-ionic surfactants on the electronic spectra of 2-hydroxy-5-nitrophenylazo-4-[3methyl-1-(4" -sulfophenyl)-5-pyrazolone]," Dyes and Pigments, vol. 44, no. 3, pp. 181-193, 2000.

[2] A. Navarro and F. Sanz, "Dye aggregation in solution: study of C.I. direct red I," Dyes and Pigments, vol. 40, no. 2-3, pp. 131-139, 1999.

[3] J. Tao, G. Mao, and L. Daehne, "Asymmetrical molecular aggregation in spherulitic dye films," Journal of the American Chemical Society, vol. 121, no. 14, pp. 3475-3485, 1999.

[4] F. Karci, İ. Şener, and H. Deligöz, "Azocalixarenes. 2: synthesis, characterization and investigation of the absorption spectra of azocalix[6]arenes containing chromogenic groups," Dyes and Pigments, vol. 62, no. 2, pp. 131-140, 2004.

[5] E. Torres, I. Bustos-Jaimes, and S. Le Borgne, "Potential use of oxidative enzymes for the detoxification of organic pollutants," Applied Catalysis B, vol. 46, no. 1, pp. 1-15, 2003.

[6] H. Yousefi, A. Yahyazadeh, M. Reza Yazdanbakhsh et al., "Synthesis, spectral features and biological activity of some novel hetarylazo dyes derived from 6-amino-1,3-dimethyluracil," Journal of Molecular Structure, vol. 1015, pp. 27-32, 2012.

[7] G. Hallas and J.-H. Choi, "Synthesis and properties of novel aziridinyl azo dyes from 2-aminothiophenes-part 2: application of some disperse dyes to polyester fibres," Dyes and Pigments, vol. 40, no. 2-3, pp. 119-129, 1999.

[8] A. Demirbas, D. Sahin, N. Demirbas, and S. A. Karaoglu, "Synthesis of some new 1,3,4-thiadiazol-2-ylmethyl-1,2,4-triazole 
derivatives and investigation of their antimicrobial activities," European Journal of Medicinal Chemistry, vol. 44, no. 7, pp. 2896-2903, 2009.

[9] K. S. Bhat, B. Poojary, D. J. Prasad, P. Naik, and B. S. Holla, "Synthesis and antitumor activity studies of some new fused 1,2,4-triazole derivatives carrying 2,4-dichloro-5-fluorophenyl moiety," European Journal of Medicinal Chemistry, vol. 44, no. 12, pp. 5066-5070, 2009.

[10] G. B. Bagihalli, P. G. Avaji, S. A. Patil, and P. S. Badami, "Synthesis, spectral characterization, in vitro antibacterial, antifungal and cytotoxic activities of $\mathrm{Co}(\mathrm{II}), \mathrm{Ni}(\mathrm{II})$ and $\mathrm{Cu}(\mathrm{II})$ complexes with 1,2,4-triazole Schiff bases," European Journal of Medicinal Chemistry, vol. 43, no. 12, pp. 2639-2649, 2008.

[11] Z. H. Chohan, S. H. Sumrra, M. H. Youssoufi, and T. B. Hadda, "Metal based biologically active compounds: design, synthesis, and antibacterial/antifungal/cytotoxic properties of triazolederived Schiff bases and their oxovanadium(IV) complexes," European Journal of Medicinal Chemistry, vol. 45, no. 7, pp. 2739-2747, 2010.

[12] K. Zamani, K. Faghihi, T. Tofighi, and M. R. Shariatzadeh, "Synthesis and antimicrobial activity of some pyridyl and naphthyl substituted 1,2,4-triazole and 1,3,4-thiadiazole derivatives," Turkish Journal of Chemistry, vol. 28, no. 1, pp. 95-100, 2004.

[13] E. R. Fernandez, J. L. Manzano, J. J. Benito, R. Hermosa, E. Monte, and J. J. Criado, "Thiourea, triazole and thiadiazine compounds and their metal complexes as antifungal agents," Journal of Inorganic Biochemistry, vol. 99, no. 8, pp. 1558-1572, 2005.

[14] D. R. Waring and G. Hallas, The Chemistry and Applications of Dyes, Plenum Press, New York, NY, USA, 1990.

[15] A. T. Mavrova, D. Wesselinova, Y. A. Tsenov, and P. Denkova, "Synthesis, cytotoxicity and effects of some 1,2,4-triazole and 1,3,4-thiadiazole derivatives on immunocompetent cells," European Journal of Medicinal Chemistry, vol. 44, no. 1, pp. 63-69, 2009.

[16] C. T. Keerthi Kumar, J. Keshavayya, T. Rajesh, and S. K. Peethambar, "Synthesis, characterization and biological activity of heterocyclic azo dyes derived from 2-aminobenzothiozole," International Journal of Pharmacy and Pharmaceutical Sciences, vol. 5, no. 1, pp. 296-301, 2013.

[17] A. H. Shridhar, J. Keshavayya, H. Joy Hoskeri, and R. A. Shoukat Ali, "Synthesis of some novel bis 1,3,4-oxadiazole fused azo dye derivatives as potent antimicrobial agents," International Research Journal of Pure \& Applied Chemistry, vol. 3, pp. 119129, 2011.

[18] B. A. Arthington-Skaggs, M. Motley, D. W. Warnock, and C. J. Morrison, "Comparative evaluation of PASCO and National Committee for Clinical Laboratory Standards M27-A broth microdilution methods for antifungal drug susceptibility testing of yeasts," Journal of Clinical Microbiology, vol. 38, no. 6, pp. 2254-2260, 2000.

[19] L. Rocha, A. Marston, O. Potterat, M. A. C. Kaplan, H. StoeckliEvans, and K. Hostettmann, "Antibacterial phloroglucinols and flavonoids from Hypericum brasiliense," Phytochemistry, vol. 40, no. 5, pp. 1447-1452, 1995.

[20] J. D. MacLowry, M. J. Jaqua, and S. T. Selepak, "Detailed methodology and implementation of a semiautomated serial dilution microtechnique for antimicrobial susceptibility testing," Applied Microbiology, vol. 20, no. 1, pp. 46-53, 1970.

[21] A. Portillo, R. Vila, B. Freixa et al., "Antifungal activity of Paraguayan plants used in traditional medicine," Journal of Ethnopharmacology, vol. 76, no. 1, pp. 93-98, 2001.
[22] A. H. Shridhar, J. Keshavayya, S. K. Peethambar, and H. Joy Hoskeri, "Synthesis and biological activities of Bis alkyl 1,3,4oxadiazole incorporated azo dye derivatives," Arabian Journal of Chemistry, 2012.

[23] M. S. Blois, "Antioxidant determinations by the use of a stable free radical," Nature, vol. 181, pp. 1199-1200, 1958.

[24] T. C. P. Dinis, V. M. C. Madeira, and L. M. Almeida, "Action of phenolic derivatives (acetaminophen, salicylate, and 5aminosalicylate) as inhibitors of membrane lipid peroxidation and as peroxyl radical scavengers," Archives of Biochemistry and Biophysics, vol. 315, no. 1, pp. 161-169, 1994.

[25] D. L. Pavia, G. M. Lampman, and G. S. Kriz, Introduction to Spectroscopy, Bellingham, Wash, USA, 1996.

[26] L. Scorzoni, T. Benaducci, A. M. F. Almeida, D. H. S. Silva, V. S. Bolzani, and M. J. S. Mendes-Giannini, "Comparative study of disk diffusion and microdilution methods for evaluation of antifungal activity of natural compounds against medical yeasts Candida spp. and Cryptococcus sp.," Revista de Ciências Farmacêuticas Básica e Aplicada, vol. 28, no. 1, pp. 25-34, 2007.

[27] J. Baumann, G. Wurm, and V. Bruchhausen, "Prostaglandin synthetase inhibiting and $\mathrm{O}_{2}$-radical scavenging properties of some flavonoids and related phenolic compounds," NaunynSchmiedeberg's Archives of Pharmacology, vol. 27, p. 308, 2002.

[28] J. R. Soares, T. C. P. Dinis, A. P. Cunha, and L. M. Almeida, "Antioxidant activities of some extracts of Thymus zygis," Free Radical Research, vol. 26, no. 5, pp. 469-478, 1997.

[29] F. Yamaguchi, T. Ariga, Y. Yoshimura, and H. Nakazawa, "Antioxidative and anti-glycation activity of garcinol from Garcinia indica fruit rind," Journal of Agricultural and Food Chemistry, vol. 48, no. 2, pp. 180-185, 2000.

[30] B. Halliwell, "Reactive oxygen species in living systems: source, biochemistry, and role in human disease," American Journal of Medicine, vol. 91, no. 3, p. 1422, 1991. 

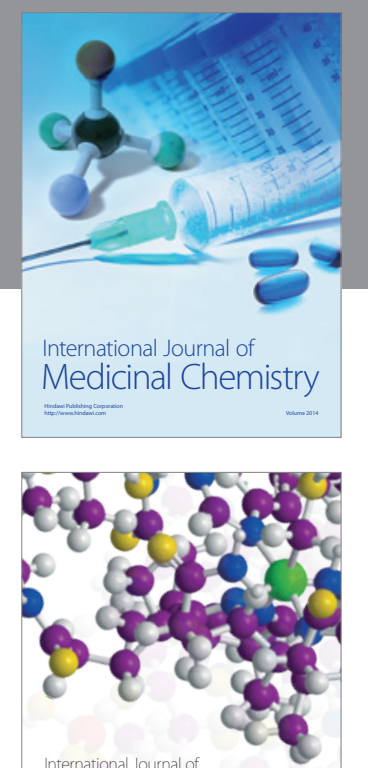

\section{Carbohydrate} Chemistry

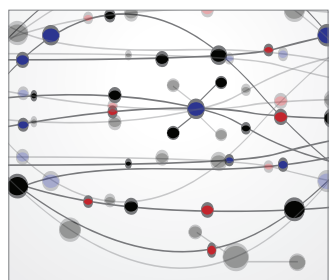

The Scientific World Journal
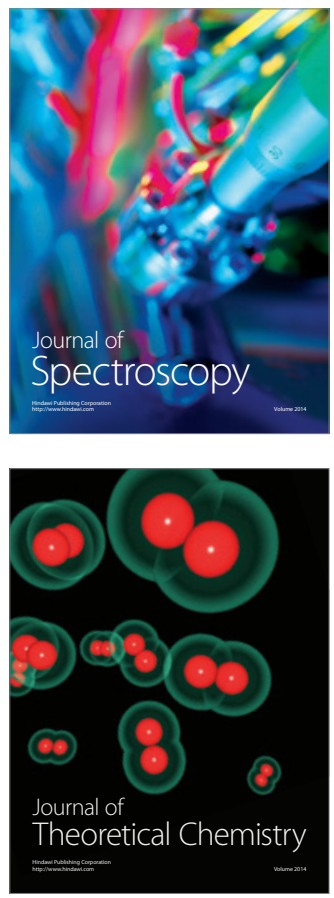
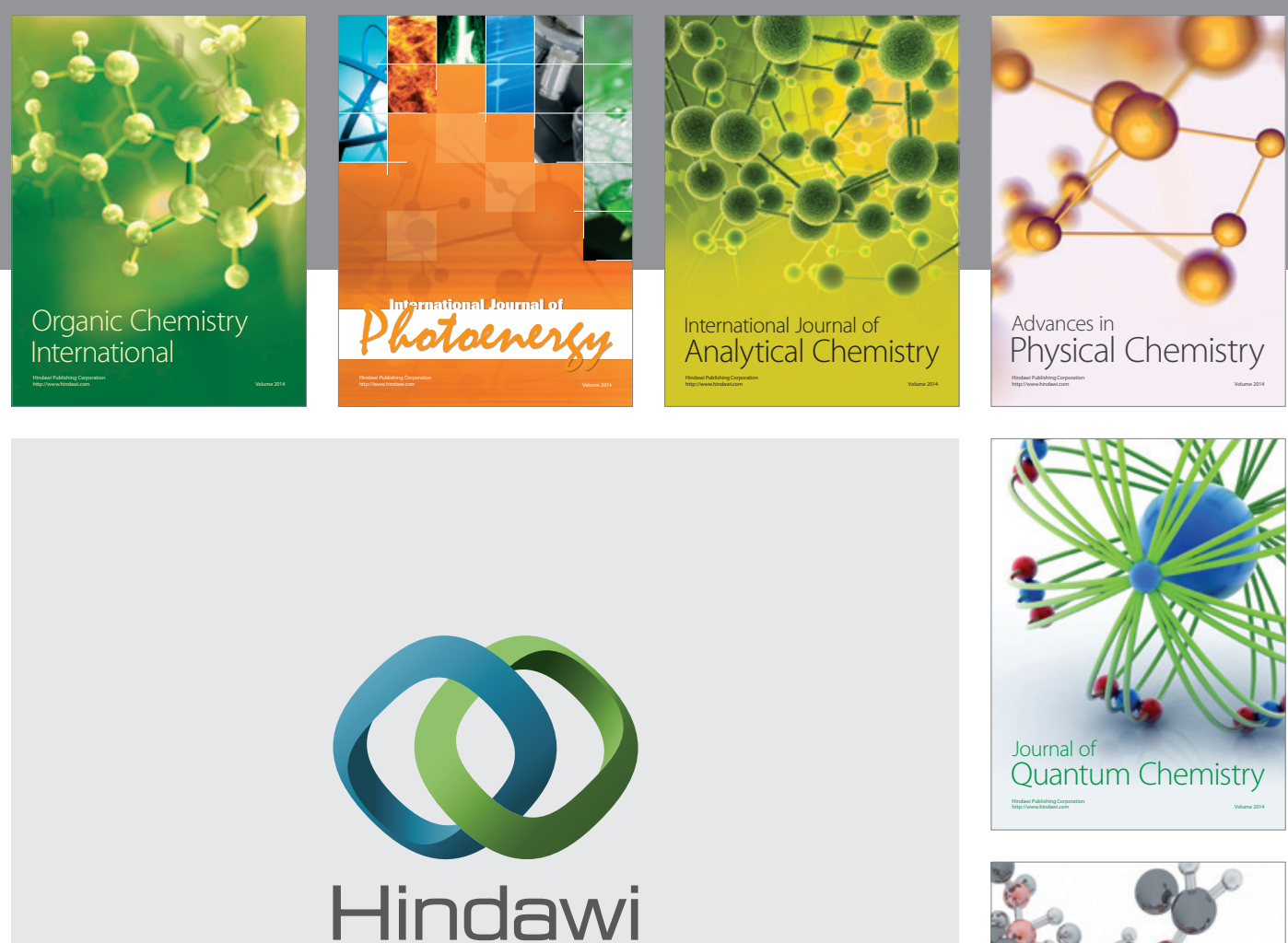

Submit your manuscripts at

http://www.hindawi.com

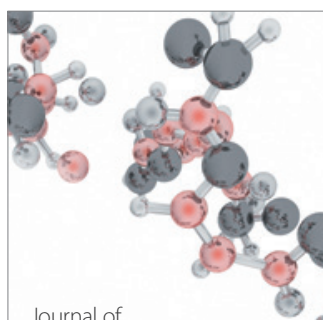

Analytical Methods

in Chemistry

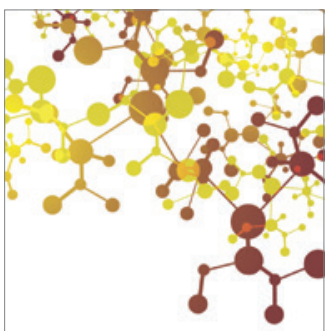

Journal of

Applied Chemistry

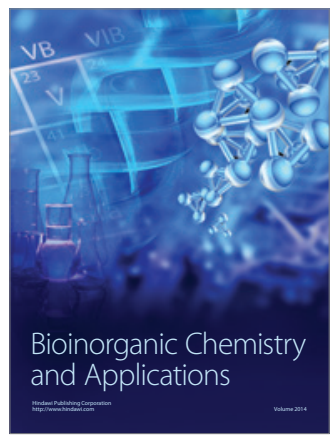

Inorganic Chemistry
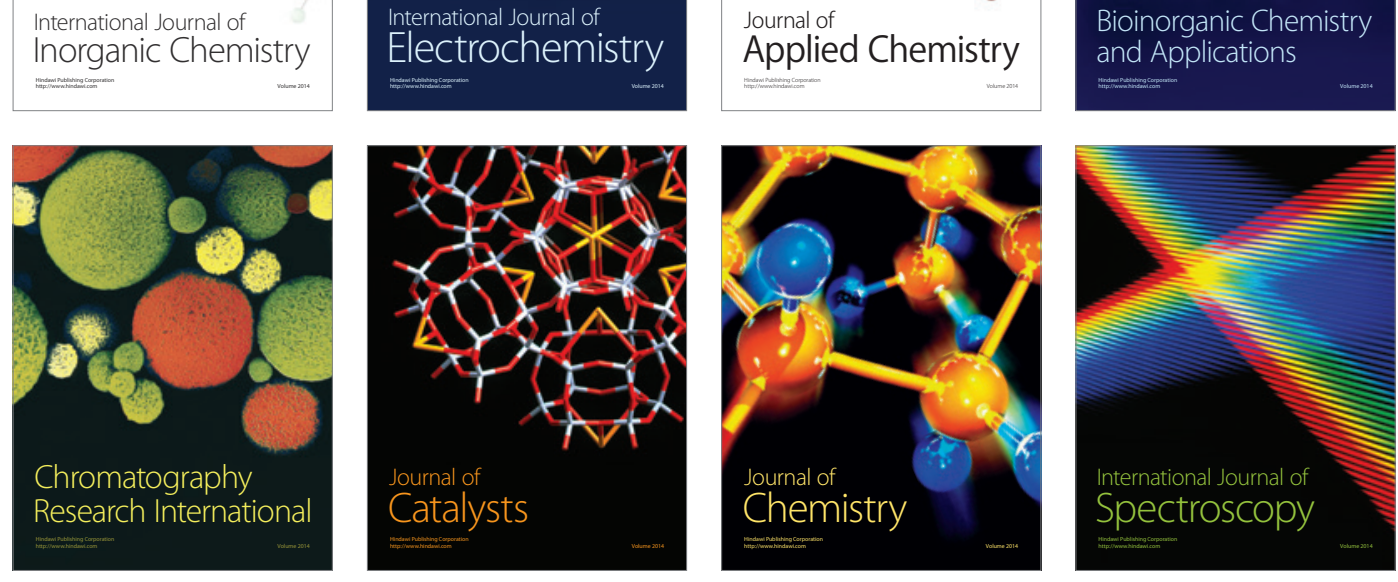